\title{
REMOÇÃO DE DENTE RETIDO EM SEIO MAXILAR: RELATO DE UM CASO CLÍNICO
}

Dhiogo Batisti SATO, Leonardo Silva BENATO, João Luiz CARLINI

Quando nos deparamos com exodontias na região posterior da maxila devemos considerar e avaliar a relação das raízes destes dentes com seio maxilar. A avaliação deverá ser criteriosa pois não é incomum ocorrer acidentes com fraturas ósseas do alvéolo, comunicação bucossinusal, fratura de raízes e deslocamento de dentes ou fragmentos para interior do seio maxilar. Este trabalho relata a remoção cirúrgica de um terceiro molar superior que foi acidentalmente deslocado para o interior do seio maxilar comprovado através de exame clínico e radiográfico. O tratamento cirúrgico foi através do acesso de Caldwell-Luc, expondo o interior do seio maxilar, o dente foi retirado com aspirador potente e pinça de Kely. Após a sutura, o paciente foi orientado em relação aos cuidados pós-operatórios especiais e a medicação necessária para esta situação particular.

Palavras-chave: Seio maxilar; Terceiro molar; cirurgia bucal 